\title{
ANEURYSMAL BONE CYST (ABC) IN FIFTH METACARPAL RIGHT HAND OF A MALE CHILD WITH HEMOPHILIA TREATED BY STEROID INJECTION: A CASE REPORT
}

\section{KISTA TULANG ANEURISMA PADA METACARPAL KELIMA TANGAN KANAN ANAK LAKI-LAKI DENGAN HEMOPHILIA DITERAPI DENGAN INJEKSI STEROID: SEBUAH LAPORAN KASUS}

\author{
Agus Wahyudi', Mujaddid Idulhaq ${ }^{2}$, Rhyan Darma Saputra ${ }^{2}$, Pamudji Utomo ${ }^{2}$ \\ ${ }^{1}$ Resident of Orthopaedic \& Traumatology, Faculty of Medicine Universitas Sebelas Maret Surakarta \\ ${ }^{2}$ Staff of Orthopaedic \& Traumatology, Sub Musculoskeletal Tumor, Faculty of Medicine Universitas \\ Sebelas Maret Surakarta, Dr. Moewardi General Hospital, and Prof. DR.R Soeharso Orthopaedic \\ Hospital Surakarta
}

\begin{abstract}
Aneurysma bone cyst $(A B C)$ is a rare case, rapidly growing, and destructive benign bone tumor that rarely involves the bones of the hand. Pathogenesis of these tumors remains controversial and may be vascular, traumatic, or genetic disorders. This study aimed to evaluate patient's out come after steroid injection. A male child presented with a history of pain and local swelling over his fifth metacarpal right hand of two months duration with hemofilia condition. Physical and radiographic examination of the hand was consistent with aneurysmal bone cyst. The patient the VIII factor 2 hours before doing steroid injection on his lump over fifth metacarpal right hand. A month evaluation after injection for this patient, we had a good result clinically and radiologically. Radiological evaluation obtained appearance of cortex thickening on the bone affected. We concluded that steroid injection should be considered as one of ABC's treatment with hemophilia, but the outcome still needed more evaluation.
\end{abstract}

Keywords: Aneurysmal Bone Cyst, Hemophilia, Steroid Injection

\section{ABSTRAK}

Kista tulang aneurisma adalah kasus yang jarang terjadi, tumbuh dengan cepat, dan tumor tulang jinak destruktifyang jarang melibatkan tulang-tulang tangan. Patogenesis tumor ini masih kontroversial dan mungkin bersifat kelainan vaskular, traumatis, atau genetik. Penelitian ini bertujuan untuk mengevaluasi pasien setelah injeksi steroid. Seorang anak laki-laki dengan riwayat nyeri dan pembengkakan lokal pada metacarpal kelima tangan kanannya selama dua bulan dengan kondisi hemofilia. Pemeriksaan fisik dan radiografi tangan menegakkan adanya kista tulang aneurisma. Pasien diberi faktor VIII 2 jam sebelum injeksi steroid pada benjolan di atas metacarpal kelima tangan kanannya. Evaluasi sebulan setelah injeksi untuk pasien ini, kami memiliki hasil yang baik secara klinis dan radiologis. Evaluasi radiologis diperoleh penampilan penebalan korteks pada tulang yang terkena. Kami menyimpulkan bahwa injeksi steroid harus dipertimbangkan sebagai salah satu pengobatan kista tulang aneurisma dengan hemofilia, namun hasilnya masih perlu evaluasi lebih lanjut.

Kata kunci: Kista Tulang Aneurisma, Hemofilia, Injeksi steroid

How To Cite: Wahyudi, A., Idulhaq, M., Saputra, R., \& Utomo, P. (2020). ANEURYSMAL BONE CYST (ABC) IN FIFTH METACARPAL RIGHT HAND OF A MALE CHILD WITH HEMOPHILIA TREATED BY STEROID INJECTION: A CASE REPORT. Biomedika, 12(2), 85-89. doi:https://doi.org/10.23917/biomedika.v12i2.10541

DOI: https://doi.org/10.23917/ biomedika.v12i2.10541 


\section{INTRODUCTION}

Aneurysmal bone cysts $(\mathrm{ABC})$ are benign bone lesions which usually arise in childhood or early adulthood. Patients usually complain for pain in the affected skeletal region, and rarely a pathological fracture is evident. A plain radiogram typically reveals an expansile osteolytic lesion, whereas magnetic resonance tomography showing characteristic fluid-fluid levels due to blood sedimentation can give valuable information that assists in diagnosis. Biopsy is obligatory, as the telangiectatic variant of osteogenic sarcoma needs to be taken into account in the differential diagnosis of the lesion. (Brosjö et al., 2013).

The nature and histogenesis of $\mathrm{ABC}$ are still unclear; it is classified as an indeterminate tumor, of intermediate malignancy, locally aggressive. It was long thought to be caused by intraosseous or subperiosteal hemorrhage due to abnormal venous circulation, activating osteoclasts and inducing bone resorption and local remodeling. This theory is no longer accepted for primary $\mathrm{ABC}$, which involves rearrangement of USP6 oncogene, on chromosome 17, but remains plausible for secondary $\mathrm{ABC}$, which does not show translocation. (Nielsen et al., 2013) $\mathrm{ABC}$ is encountered at all ages, but most patients are in their second decade and 75 to $90 \%$ of cases occur before that age of $20 ; \mathrm{ABC}$ is rarer after the age of 30 and exceptional after 50. It usually occurs singly. (Docquier and Delloye, 2011; Nielsen et al., 2013)

Most commonly, $\mathrm{ABCs}$ are found in the long bones of the lower extremity or the posterior elements of the spine and may involve the hands in about $5 \%$ of cases (Rapp et al., 2012). Even though such simple treatments appear to work in the majority of cases, it should be noted that $\mathrm{ABCs}$ present with a broad spectrum of biological aggressiveness, and these techniques may fail in the case of aggressive lesions. This has been illustrated by Louahem et al. (2012), who described the clinical and radiological evolution of $\mathrm{ABCs}$ after biopsy.

There is no consensus in the literature on the best treatment for aneurysmal bone cyst. No treatments, other than wide resection, guarantee cure. Surgery was classically the treatment of choice in ABC ( Docquier and Delloye, 2011; Varshney et al., 2010). Other methods show failure rates of 15 to $30 \%$, so that the least aggressive techniques are implemented first, sometimes associated to osteosynthesis in case of severe fragility. Methylprednisolone acetate 
injection is to be avoided, as it may exacerbate the lesion. (Docquier and Delloye, 2011) Previously, sclerotherapy has been attempted, with different sclerosing agents and with variable success. ( Mascard et al., 2015).

We report here what is to our knowledge the case of $\mathrm{ABC}$ intralesional decompression using steroid due to patient's comorbid. The goal of the treatment is to know that steroid injection can be used as an alternative treatment for ABCs especially for those who have comorbidities for surgery.

\section{CASE REPORT}

A male child presented with lump on his back of right hand. The lump appeared since two months before admission, getting bigger by time and also pain. There was no history of trauma, night pain, loss of appetite, and loss of body weigth. His past medical history was hemophilia and under controlled by pediatric department. The patient also had the normal growth and development.

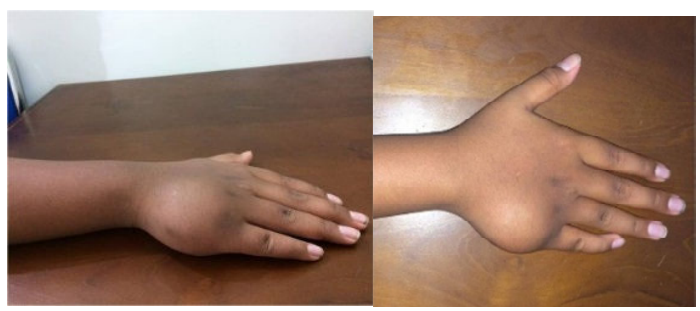

Figure 1. Clinical photograph of patient

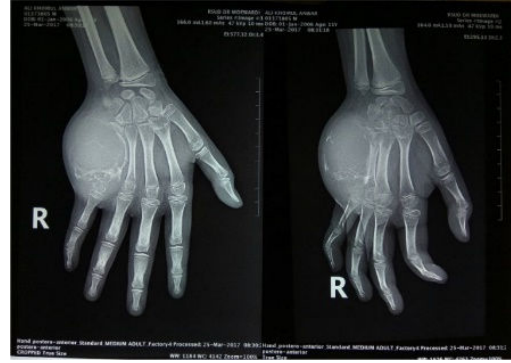

Figure 2. Pre methylprednisolone injection X-Ray

On physical examination, the patient felt pain on his back of the right hand and the lump is bigger than before (figure 1). He could do the daily activities normally. The patient did the routine check up to pediatricians for his hemophilia and consulted to orthopaedic department due to his new complaint.

On radiology examination, there was cortical destruction of his $5^{\text {th }}$ metacarpal bone of right hand and showed radiolucent cystic lession (figure 2). The patient also had MRI evaluation on his right hand (figure 3).

After being examined clinically and radiologically, the patient decided to have steroid injection through the lump 3 times with the interval time between each injection procedure is a week during a month. 

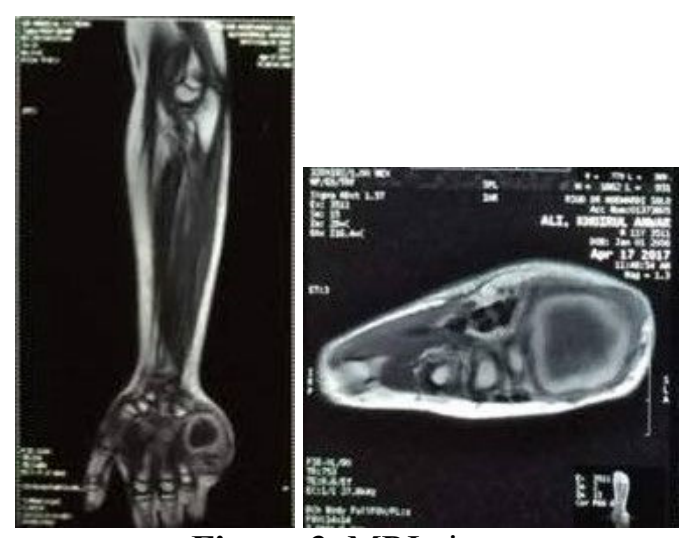

Figure 3. MRI view
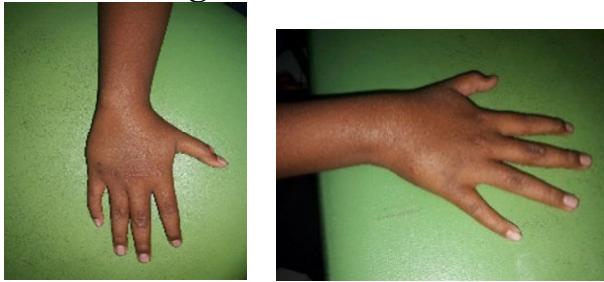

Figure 4. Clinical view post $3^{\text {rd }}$ methylprednisolone injection

The dose of the steroid based on volume of the lession. The first injection we injected 3 $\mathrm{mL}$ contains $187,5 \mathrm{mg}$ methylpredsolone. The second injection injected $2 \mathrm{~mL}$ contains $125 \mathrm{mg}$ of methylrednisolone. The third injection injected $1 \mathrm{~mL}$ contains $62,5 \mathrm{mg}$ of methylrednisolone. Then we do clinical (figure 4) and radiological evaluation after complete treatment (figure 5).

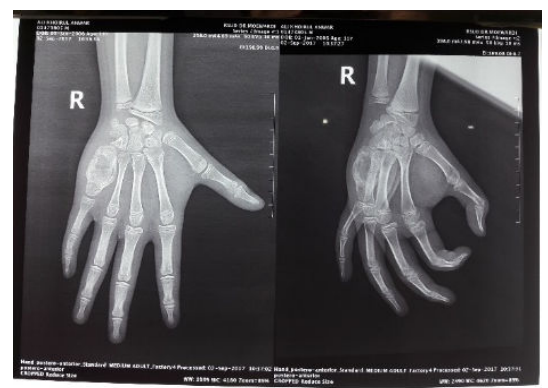

Figure 5. Post $3^{\text {rd }}$ methylprednisolone injection $X-$ Ray

After having steroid injection the patient showed good result clinically and radiologically.
On the last evaluation after $3^{\text {rd }}$ steroid injection procedure, the radiograph shown thickening of metacarpal cortex and the lession became smaller than before.

\section{DISCUSSION}

In this study, we focused on the post steroid injection evaluation clinically and based on radiograph view. In the previous study, methylprednisolone is not used as single dose but combined with calcitonin injection as sclerotherapy agent for ABCs. The result was success based on imaging by comparing radiographs of the lesion before and after treatment. From their study there were 9 patients comprised in the study. 1 patient did not have any clinical and imaging follow up. For other 8 patients, six patients had complete symptomatic relief and two patients had partial symptomatic relief after injection. Imaging follow up revealed substantial imaging response in 4 out of 8 patients $(50 \%)$, there was a partial imaging response in 2 patients (25\%) and no imaging response in 2 out of 8 patients $(25 \%)$. (Connie $e t$ al., 2016)

In our study, found that single dose of steroid injection on aneurysmal bone cyst had the good result to the patient. 


\section{CONCLUSION}

Steroid injection of ABC's is safe and

effective treatment with minimal need cost.

Long term follow up should be evaluated to

know about the local recurrence.

\section{REFFERENCES}

Brosjö, O., Pechon, P., Hesla, A., Tsagozis P., and Bauer, H. 2013. Sclerotherapy with polidocanol for treatment of aneurysmal bone cysts. Acta Orthop. 84: 502-5

Connie ,Y.C., Susan, V.K., Ambrose, J.H., Joseph, F.S., Martin, T., and Miriam, A. B. 2016. Treatment of aneurysmal bone cyst by percutaneous CT-guided injection of calcitonin and steroid. Skeletal Radiol.

Docquier, P.L. and Delloye, C. 2011. Kyste osseux anévrysmal. In: EMC. Elsevier. Masson SAS.
Louahem, D., Kouyoumdjian, P., Ghanem, I., Mazeau, P., Perrochia, H., L'Kaissi, M., and Cottalorda, J. 2012. Active aneurysmal bone cysts in children: possible evolution after biopsy. $J$ Child Orthop. 6:333-8.

Mascard, E., Gomex-Brouchet, A., and Lambot, K. 2015. Bone cysts : Unicameral and aneurysmal bone cysts. Orthop Traumatol Surg Res.101:S119-127

Nielsen, G.P., Fletcher, J.A., and Oliveira, A.M. 2013. Aneurysmal bone cyst. In: Fletcher BJA, Hogendoorn PCW, Mertens F, editors. WHO classification of tumours of soft tissue and bone. Lyon. IARC. p. 3489.

Rapp, T.B., Ward, J.P., and Alaia, M.J. 2012. Aneurysmal bone cyst. J Am Acad Orthop Surg. 20(4):233e241.

Varshney, M.K., Rastogi, S., Khan, S.A., and Trikha, V. 2010. Is sclerotherapy better than intralesional excision for treating aneurysmal bone cysts? Clin Orthop Relat Res. 468(6). Pp: 1649-59 